Austin, R.M. 266, 281

Boon, M.E. 266

Chantziantoniou, N. 262, 266

Donnelly, A.D. 266

Fuentes-Martinez, N. 305

Mukherjee, M. 266

Nayar, R. 359
Osamura, R.Y. 299

Schmitt, F.C. 373

Schneider, V. 338

Skoog, L. 305

Syrjänen, K.J. 259, 316

Tani, E. 305

Vielh, P. 373

Wilbur, D.C. 345,359

\title{
Subject Index Vol. 61, No. 4-5, 2017
}

Acta Cytologica 338

Analytic cytology 345

Atypical cells 299

Automation 345

Breast cytology 305

Cancer screening 299

- staging 299

Carcinoma in situ 299

Causal agent 316

Cervical cancer 299, 316

- cytology 299, 359

- intraepithelial neoplasia 316

- screening 338

Cornification 266

Cytology technique 305

Cytopathology 338

Dysplasia 316
Editorials 338

Endometrial cytology 281

- explants 281

Fine-needle aspiration 373

- - cytology 305

Fixation 266

Genital wart 316

Global burden 316

Histology 316

History 338

Human papillomavirus 316

Immunocytochemistry 373

Koilocyte 316

Molecular techniques 373
Nongynecologic cytology 373

Oncogenic virus 316

Pap smear 316

- stain 266

- test 266, 359

Papanicolaou 281

- stain 266

Prophylactic vaccines 316

Quantitative cytology 345

Reporting terminology 359

The Bethesda System 359

Vaginal fluid smear 266

Viral cytopathic change 316 